\title{
Formulation of baby biscuits with substitution of wood grasshopper flour (Melanoplus cinereus) as an alternative complementary food for children
}

\author{
Dewi, T., Vidiarti, A.N., Fitranti, D.Y., Kurniawati, D.M. and *Anjani, G. \\ Nutrition Science Program, Medical Faculty of Diponegoro University Semarang, Indonesia
}

\author{
Article history: \\ Received: 31 January 2020 \\ Received in revised form: 5 \\ April 2020 \\ Accepted: 27 April 2020 \\ Available Online: 30 May \\ 2020
}

\section{Keywords:}

Complementary food,

Baby biscuits,

Wood grasshopper flour,

Nutrient content

\section{DOI:}

https://doi.org/10.26656/fr.2017.4(S3).S25

\begin{abstract}
The provision of complementary food is one effort to overcome nutrition problems in vulnerable groups such as children aged 12-24 months. Giving inadequate complementary food can cause malnutrition. The prevalence of malnutrition in Yogyakarta, Indonesia in 2017 was $8.26 \%$. While in this region, there is a kind of insect, wood grasshopper, that commonly consumed as local food as a source of protein. In this study, wood grasshopper flour was used to substitute wheat flour to develop baby biscuits and analyze the amino acid, energy, nutrient content; protein quality; and organoleptic properties. An experimental study of a complete randomized one factor by substitution of wood grasshopper flour with variations in substitution of $0 \%, 5 \%, 7 \%$, and $10 \%$. Wood grasshopper is obtained directly from GunungKidul Regency, Yogyakarta. Substitution of wood grasshopper flour could enhance energy, protein, dietary fiber, zinc, and amino acid content level of lysine, leucine, phenylalanine, arginine. Whereas, decrease carbohydrate and methionine content. The most suitable energy, nutrient content, quality protein, and the preferred organoleptic of baby biscuits and fullfil the Indonesian regulation of complementary food is the formulation with the substitution of wood grasshopper flour as much as $5 \%$. The suggested serving size of baby biscuits with the substitution of wood grasshopper flour is 6 pieces (60 g). Consumption of one serving size of baby biscuits with the substitution of wood grasshopper flour contributes to the adequacy of protein per day as much as $24-38 \%$ RDA of children aged 12-24 months from each formulation
\end{abstract}

\section{Introduction}

Complementary feeding is a nutrient-dense feeding activity for vulnerable groups, such as children aged 1224 months. The complementary feeding program is implemented as a nutritional intervention to improve and maintain the nutritional status of undernourished children. Malnutrition problems that occur in children were often associated with a lack of energy and protein in the long run. Based on the 2014 Survey Diet Total (SDT), reported that more than half of children under five $(55.7 \%)$ have less energy intake than the Recommended Dietary Allowance (RDA) (Ministry of Health RI, 2016). In 2018 Globally, 49 million (7.3\%) children under five were wasted of which nearly 17 million (2.4\%) were severely wasted (UNICEF, 2019). Malnutrition prevalence in Indonesia based on Riskesdas 2013 was $19.6 \%$ and decreased in 2018 to $17.7 \%$ (Agency of Health Research and Development, 2013; Ministry of Health RI, 2019). The prevalence of undernourished children under five in the Yogyakarta in
2015 was $8.04 \%$ and increased in 2016 to $8.83 \%$ then decreased in 2017 to $8.26 \%$. The prevalence rate for the last three years is still around number 8 which shows that the efforts made to reduce the prevalence of undernutrition children in Yogyakarta have not been maximally achieved. GunungKidul Regency (7.34\%) was in the top 3 in districts with the highest prevalence of undernourished children under five in Yogyakarta (Public Health Office, 2017). Malnutrition problems need to get intervention as soon as possible because it can cause growth and mental development disorders of children. One of the solutions was to diversify food based on innovation and nutritional standards. As an effort to diversify complementary food, it was necessary to develop a formulation of a functional complementary food based on local food. One of the potential local food in GunungKidul Regency, Yogyakarta was wood grasshopper (Melanoplus cinereus). Wood grasshopper has good nutrient content for the body. Based on previous research the protein content of wood grasshoppers was 57.3\% (Blásquez et al., 2012).The 
abundant availability of wood grasshoppers in the GunungKidul Regency has not yet been utilized to its full potential, only limited to public consumption, especially among adults as fried or stewed side dishes. The objective of this study was to evaluate the proximate composition of baby biscuits with wood grasshopper flour substitution as well as the mineral, amino acids, protein quality, and sensory characteristics.

\section{Materials and methods}

\subsection{Source of materials and preparation}

Wheat flour and other baking ingredients such as margarine, skimmed milk powder, sugar, egg yolk were purchased at the local market. Wood grasshopper was obtained from GunungKidul Regency, Yogyakarta, Indonesia.

\subsection{Processing method}

\subsubsection{Production of wood grasshopper flour}

Wood grasshopper flour was prepared through several steps. First, the wings, claws, and internal organs of the wood grasshopper were removed, soaked and washed with warm moisture and lime juice. Furthermore, cut into 3 parts and dried at $60^{\circ} \mathrm{C}$ for $24 \mathrm{hrs}$. Dried wood grasshopper sample was ground separately in an electric grinder and sifted through an 80-mesh sieve to obtain fine powders. The obtained powder was hygienically packed and stored at room temperature in an airtight container for further use.

\subsubsection{Preparation and production of baby biscuits}

Wet ingredients (margarine and egg yolk) were mixed together and then combined with dry ingredients according to the recipe presented in Table 1 . The dough was mixed for 10 mins to obtain a homogeneous consistency. The dough was then weighed as much as 12 $\mathrm{g}$, flattened to a uniform diameter of $60 \mathrm{~mm}$ and baked at $120^{\circ} \mathrm{C}$ for 15 mins. The biscuits with the wood grasshopper flour substitution in amounts of 5, 7, and $10 \%$ - in relation to the wheat flour - were prepared in the same way as the control sample (biscuits without wood grasshopper flour). The biscuits were packaged in airtight until needed for sensory evaluation and other analyses.

\subsection{Chemical analyses of baby biscuits}

The chemical compositions of biscuits were determined according to the methods of the Association of Official Analytical Chemists International (AOAC, 1995): the total protein content by the Kjeldahl procedure; amino acids (leucine, lysine, phenylalanine, and methionine) contents by High Performance Liquid Chromatography (HPLC) method (Ahmed et al., 2016); fat content by the Soxhlet method; total carbohydrate content was calculated by difference; dietary fiber by the multienzyme method. Moisture content was determined using the direct drying method. Ash was obtained by incinerating at $400^{\circ} \mathrm{C}$ (1st stage) and $550^{\circ} \mathrm{C}$ (2nd stage) until constant weight. Mineral analyses such as zinc content by Atomic Absorption Spectroscopy (AAS) method and iron content by Spectrophotometry method. Analyses of protein quality by the in vitro method (Youssef, 2015).

\subsection{Sensory characteristics}

Sensory evaluation of the samples was carried out using 25 semi-trained panelists selected from students of the Nutrition Department, Diponegoro University. The wood grasshopper-biscuit samples of various proportions were evaluated for colour, texture, aroma and taste with the hedonic test. Determination of biscuits with wood grasshopper flour substitution acceptability was obtained by using a hedonic test with four scales, $1=$ like extremely; 2 = like, 3 = dislike; 4 = dislike extremely.

\subsection{Statistical analysis}

The experimental data were subjected to analysis of variance, at the confidence level of $\alpha=0.05$. Descriptive statistical analysis test was used for amino acid profile analysis. One-Way ANOVA test for energy, fat, carbohydrate, ash, and protein quality analysis. KruskalWallis test for protein, dietary fiber, moisture, zinc, and iron analysis. Friedman test for organoleptic properties analysis.

Table 1. Components use for the preparation of biscuit dough

\begin{tabular}{lcccc}
\hline Components & Control Sample (0\%) & F1 (\%) & F2 (\%) & F3 (\%) \\
\hline Wheat flour & $\mathbf{3 6 . 4}$ & $\mathbf{3 1 . 4}$ & $\mathbf{2 9 . 4}$ & $\mathbf{2 6 . 4}$ \\
Margarine & 18.2 & 18.2 & 18.2 & 18.2 \\
Sugar & 18.2 & 18.2 & 18.2 & 18.2 \\
Skimmed milk powder & 18.2 & 18.2 & 18.2 & 18.2 \\
Egg yolk & 9.1 & 9.1 & 9.1 & 9.1 \\
Wood grasshopper flour & $\mathbf{0}$ & $\mathbf{5}$ & $\mathbf{7}$ & $\mathbf{1 0}$ \\
\hline
\end{tabular}

Ingredients of the recipe, the number of which changes are marked in bold font 


\section{Results and discussion}

\subsection{Nutrient content analyses of wood grasshopper flour}

Nutrient content analyses of wood grasshopper flour were required as a base for determining experimental formulations in this study. The nutrient content of the wood grasshopper flour was represented in Table 2 . Wood grasshopper was one of the local foods in GunungKidul Regency, Yogyakarta which has a high protein content. The wood grasshopper flour can be used as a substitute material to increase the nutritional value of complementary food. From data presented in Table 2, the content of protein, fat, carbohydrate, ash, and moisture were $60.55 \%, 9.18 \%, 14.23 \%, 2.27 \%$, and $13.77 \%$ in order. While, amino acids content such as methionine, arginine, leucine, lysine and phenylalanine were $0.78 \%, 27.51 \%, 7.67 \%, 5.52 \%$, and $2.03 \%$. The similar result was obtained by Blasquez, who reported that the chemical composition of wood grasshopper flour (Melanoplus cinereus) was protein $58.90 \%$, fat $11.00 \%$, carbohydrate $6.50 \%$, and ash $3.94 \%$. Also, the content of leucine $5.82 \%$, lysine $6.17 \%$, and phenylalanine $2.25 \%$ (Blásquez et al., 2012). Proximate content in wood grasshopper flour was used as a basis for determining biscuit formulations by looking at and adjusting the nutrient content requirements in baby biscuits according to Indonesian regulation. Arginine could be increased growth hormone secretion, also increased the growth plate width of tibia and osteoblast surface of femur and serum growth hormone concentration, resulting in the linear growth of long bones (Jiang and Cai, 2011). Methionine, leucin, and phenylalanine required for protein synthesis and increased growth hormone secretion (Demands, 2016). Lysine could be a useful nutritional intervention for decreasing diarrhea morbidity in children (Ghosh et al., 2010).

Table 2. Nutrient content analyses of wood grasshopper flour

\begin{tabular}{lcc}
\hline \multicolumn{1}{c}{ Parameters } & Unit & Quantity \\
\hline Energy & $\mathrm{kcal}$ & 381.74 \\
Protein & $\%$ & 60.55 \\
Protein quality & $\%$ & 24.93 \\
Amino acids : & & \\
Methionine & $\%$ & 0.78 \\
Luecine & $\%$ & 7.67 \\
Phenylalanine & $\%$ & 2.03 \\
Lysine & $\%$ & 3.94 \\
Arginine & $\%$ & 27.51 \\
Fat & $\%$ & 9.18 \\
Carbohydrate & $\%$ & 14.23 \\
Ash & $\%$ & 2.27 \\
Moisture & $\%$ & 13.77 \\
Dietary fiber & $\%$ & 65.8 \\
Zinc & $\mathrm{mg}$ & 0.635 \\
Iron & $\mathrm{mg}$ & 0.13 \\
\hline
\end{tabular}

\subsection{Nutrient content analyses of wood grasshopper} biscuits

The nutrient content of the four formulations was represented in Tables 3, 4, and 5. Protein, amino acids, protein quality fat, carbohydrates, dietary fiber, moisture, ash content were represented in percent (dry basis). Energy in kcal. Minerals are represented in $\mathrm{mg} / 100 \mathrm{~g}$.

\subsection{Protein}

The substitution of wood grasshopper flour significantly increases the protein content of baby biscuits. The protein content of F0 biscuits as much as $10.61 \%$ has fulfilled the Indonesian regulation of complementary food, which is $8-12 \%$ (Ministry of Health RI, 2016) While other formulations were higher than the specification requirements. The increase in protein content along with the increase in substitution of wood grasshopper flour was caused by the protein content of wood grasshopper flour $(60.55 \%)$ was higher than the wheat flour (10\%). Consumption of baby biscuits according to serving size $(60 \mathrm{~g})$ contributes to the adequacy of protein per day as much as $24-38 \%$ RDA of children aged 12-24 months from each formulation (LIPI, 2004). Protein was used to catch-up growth of the children aged 12-24 months, the formation of tissue, and energy reserves in the body (Semba, 2016).

\subsection{Protein quality}

Based on the results of data analysis in Table 4, the protein quality of baby biscuits ranged from $69.82 \%$ $97.17 \%$. Consuming $100 \mathrm{~g}$ of biscuit protein means $69.82-96.17 \mathrm{~g}$ of digestible protein while the remaining protein is discharged through feces. The protein quality of biscuits control was significantly higher than biscuits prepared from wood grasshopper flour. The decrease in protein quality of biscuits due to the level of addition of wood grasshopper flour could be attributed to the high fiber content of wood grasshopper flour which is $65,8 \%$. According to Marono et al. (2015), the main source of fiber in grasshopper comes from chitin which is a major component of the exoskeleton in grasshopper, especially in the head, hands, and feet. Chitin cannot be degraded and absorbed by the small intestine even though chitinase has been found in the human stomach. Chitin is a major factor influencing low protein quality in grasshoppers (Marono et al., 2015). On the other hand, a decrease in protein quality can also be caused by a Maillard reaction, which is a reaction between amino acids and reducing sugars that occur during the cooking process by heat. In the Maillard reaction, the reducing sugars are linked to proteins by covalent bonds between free amino groups and carbonyl groups of reducing sugars (Teodorowicz et al., 2017). According to the 
Table 3. Proximate composition of wood grasshopper biscuits

\begin{tabular}{cllcccc}
\hline \multirow{2}{*}{ Sample } & \multicolumn{5}{c}{ Proximate composition of wood grasshopper biscuits } \\
\cline { 2 - 7 } & Energy (kcal) & Protein (\%) & Fat $(\%)$ & Carbohydrate \%) & Ash $(\%)$ & Moisture $\%)$ \\
\hline F0 & $462.63 \pm 4.99^{\mathrm{ab}}$ & $10.61 \pm 0.18^{\mathrm{a}}$ & $19.98 \pm 0.45^{\mathrm{ab}}$ & $60.09 \pm 0.54^{\mathrm{a}}$ & $7.31(6.30-7.43)^{\mathrm{a}}$ & $2.30 \pm 0.11^{\mathrm{a}}$ \\
F1 & $462.10 \pm 9.12^{\mathrm{ac}}$ & $14.28 \pm 0.07^{\mathrm{b}}$ & $19.68 \pm 1.57^{\mathrm{ac}}$ & $56.95 \pm 1.33^{\mathrm{b}}$ & $5.69(5.43-6.51)^{\mathrm{ac}}$ & $3.20 \pm 0.15^{\mathrm{b}}$ \\
F2 & $478.01 \pm 8.01^{\mathrm{cb}}$ & $15.36 \pm 0.51^{\mathrm{c}}$ & $21.97 \pm 1.56^{\mathrm{cb}}$ & $54.71 \pm 1.20^{\mathrm{bc}}$ & $4.30(4.29-4.95)^{\mathrm{b}}$ & $3.44 \pm 0.15^{\mathrm{bc}}$ \\
F3 & $474.51 \pm 5.14^{\mathrm{abc}}$ & $16.45 \pm 0.84^{\mathrm{c}}$ & $22.25 \pm 0.49^{\mathrm{abc}}$ & $52.12 \pm 0.73^{\mathrm{cd}}$ & $5.80(5.01-6.18)^{\mathrm{c}}$ & $3.51 \pm 0.27^{\mathrm{bd}}$ \\
\hline
\end{tabular}

*Values with different superscripts among the same column were significantly different $(\mathrm{p}<0.05)$

Table 4. Dietary fiber, minerals, and protein quality of wood grasshopper biscuits

\begin{tabular}{ccccc}
\hline \multirow{2}{*}{ Sample } & \multicolumn{4}{c}{ Dietary fiber, minerals, and protein quality } \\
\cline { 2 - 5 } & Dietary fiber $(\%)$ & Zinc $(\mathrm{mg})$ & Iron $(\mathrm{mg})$ & Protein quality $(\%)^{\mathrm{a}}$ \\
\hline F0 & $6.23(5.83-6.73)^{\mathrm{a}}$ & $0.075(0.074-0.075)^{\mathrm{a}}$ & $0.28 \pm 0.01^{\mathrm{ab}}$ & $96.17 \pm 2.83^{\mathrm{a}}$ \\
F1 & $11.03(10.61-12.31)^{\mathrm{b}}$ & $0.081(0.079-0.081)^{\mathrm{b}}$ & $0.40 \pm 0.06^{\mathrm{ac}}$ & $70.25 \pm 2.35^{\mathrm{b}}$ \\
F2 & $15.55(15.52-17.79)^{\mathrm{c}}$ & $0.084(0.083-0.085)^{\mathrm{c}}$ & $0.36 \pm 0.03^{\mathrm{cb}}$ & $69.82 \pm 1.72^{\mathrm{bc}}$ \\
F3 & $19.75(18.80-20.73)^{\mathrm{d}}$ & $0.109(0.091-0.126)^{\mathrm{d}}$ & $0.41 \pm 0.11^{\mathrm{abc}}$ & $69.98 \pm 12.15^{\mathrm{bd}}$ \\
\hline
\end{tabular}

*Values with different superscripts among the same column were significantly different $(\mathrm{p}<0.05)$

Table 5. Amino acids content of wood grasshopper biscuits

\begin{tabular}{lccccc}
\hline \multirow{2}{*}{ Sample } & \multicolumn{5}{c}{ Amino acids content } \\
\cline { 2 - 6 } & Methionine (\%) & Leucine (\%) & Phenylalanine (\%) & Lysine (\%) & Arginine (\%) \\
\hline F0 & $0.25 \pm 0.01$ & $1.05 \pm 0.18$ & $0.59 \pm 0.06$ & $0.56 \pm 0.15$ & $1.40 \pm 0.35$ \\
F1 & $0.11 \pm 0.01$ & $1.44 \pm 0.01$ & $0.70 \pm 0.08$ & $0.64 \pm 0.12$ & $1.69 \pm 0.48$ \\
\hline
\end{tabular}

Indonesian regulation of supplementary food protein quality for children, 12-24 months is a minimum of $70 \%$ (Ministry of Health RI, 2016).Therefore, the content of protein quality for formulation control (F0) and substitution of wood grasshopper $5 \%(\mathrm{~F} 1)$ has met the requirements.

\subsection{Amino acid}

The amino acid analysis was performed on F0 biscuit (without wood grasshopper flour substitution) and the best treatment group obtained from the sensory characteristic which was F1 (biscuit with wood grasshopper substitution 5\%). The level of methionine in F0 biscuits was higher $(0.14 \%)$ than F1 biscuits (biscuit with substitution of wood grasshopper 5\%). The decrease in methionine levels was caused by the substitution of wood grasshoppers, thereby reducing the amount of wheat flour in biscuits. Meanwhile, the level of methionine in wheat flour $(1.13 \%)$ was higher than methionine in wood grasshopper flour $(0.78 \%)$ (Shewry and Hew, 2015).Methionine was a limiting amino acid in F0 and F1 biscuits. This caused the amino acid methionine was absorbed in low amounts by the body. The levels of the amino acids lysine, leucine, phenylalanine, and arginine in F1 biscuits were higher than those of F0 biscuits. Changes in the levels of amino acids lysine, leucine, phenylalanine, and arginine have $0.08 \%, 0.11 \%, 0.39 \%$, and $0.29 \%$, respectively. The increase of amino acids in F1 biscuit was caused by the substitution of grasshopper flour. Wood grasshopper flour has higher levels of lysine, leucine, phenylalanine, and arginine than wheat flour (Mohamed et al., 2014). F1 biscuits contain higher levels of the amino acids such as lysine, leucine, phenylalanine, and arginine compared to the fortification of biscuits with 3\% carp fish protein concentrate and 3\% shark fish protein concentrate (WHO, 2002). The need for leucine, lysine, phenylalanine, and methionine in children 12-24 months were $54 \mathrm{mg} / \mathrm{kg}, 45 \mathrm{mg} / \mathrm{kg}$, $40 \mathrm{mg} / \mathrm{kg}$, and $22 \mathrm{mg} / \mathrm{kg}$ body weight per day (WHO, 2002). The calculation of amino acid requirements for children 12-24 months is done with an estimated ideal body weight of around $13 \mathrm{~kg}$. Given 60 grams (6 pieces) of F1 biscuits can fulfill $123 \%$ of leucine needs, $65.6 \%$ of lysine needs, $80.8 \%$ of phenylalanine needs, and $134.3 \%$ of methionine needs. This has been able to meet the adequacy of the amino acids leucine, lysine, phenylalanine, and methionine in children 12-24 months.

3.6 Fat

The fat content of all formulations was higher than the specification requirements for baby biscuits which is 10-18\% (Ministry of Health RI, 2016). A high level of fat in baby biscuits was due to the use of raw materials such as margarine and egg yolk. The use of margarine and egg yolk was the same in all formulations so that the increase in fat content was influenced by the percentage of substitution of wood grasshopper flour. The increase in fat content along with the increase in substitution of wood grasshopper flour was caused by the fat content of wood grasshopper flour $(9.18 \%)$ higher than the wheat flour (1\%). According to the research of Das and Mandal 
(2013) and Kourimska and Adámková (2016), grasshopper contains polyunsaturated fatty acids (PUFA), especially the content of eicosenoic, oleic, linoleic, and linolenic fatty acids. Essential fatty acids were needed by children for the growth and development of the brain and other vital organs.

\subsection{Carbohydrate}

There are no specific specification requirements for the carbohydrate content of baby biscuits. The carbohydrate content of baby biscuits tends to decrease with the addition of wood grasshopper flour because the carbohydrate content of wood grasshopper flour (14.2\%) was lower than wheat flour (76\%). Therefore, increasing the substitution of grasshopper flour causes a decrease in the carbohydrate content of baby biscuits. Children need adequate carbohydrate intake to maintain metabolism in the body. Changes in metabolism can occur due to lack of carbohydrate intakes such as the process of gluconeogenesis, specifically glucose synthesis apart from carbohydrate compounds, usually from protein and fat. It also causes the incidence of fat and protein deficiency higher in children. The release of large amounts of fatty acids from adipose tissue in the process of gluconeogenesis can inhibit the work of growth hormone in the process of growing children (Alves et al., 2014).

\subsection{Ash}

The ash content has met the requirements because based on SNI 01-7111.2-2005 about baby biscuits, the required ash content is a maximum of $3.5 \%$ (BSN, 2005). Ash is one component of food. Ash is known as an element of minerals or organic substances. This component consists of minerals such as potassium, phosphorus, sodium, and copper (Paul et al., 2016).

\subsection{Moisture}

Based on requirements for baby biscuit specifications where the maximum water content was $5 \%$, only $\mathrm{F} 2$ or $7 \%$ formulation of wood grasshopper substitutes fulfill these requirements because the addition of water to the dough only aims to make the dough easy to form so that the results of the water content analysis in the biscuits indicate abnormal distribution data. Whereas the moisture content of other formulations was higher than the specification requirements. Water content affects the texture, appearance, and taste of food. High water content was also related to the shelf life of a food or food product due to an increase in microbial activity. This can be overcome by storing the foodstuff in an airtight container and placing it at a relatively low temperature (Zambrano et al., 2019).

\subsection{Energy}

The energy content of baby biscuits with wood grasshopper flour substitution ranged from 462.10$478.01 \mathrm{kcal} / 100 \mathrm{~g}$ so that it meets the specifications for baby biscuits which is at least $400 \mathrm{kcal} / 100$ grams (Ministry of Health RI, 2016). Baby biscuits with wood grasshopper flour substitution have an energy density of $4.62-4.78 \mathrm{kcal} / \mathrm{g}$. Foods with an energy density value of 4-9 $\mathrm{kcal} / \mathrm{g}$ are classified in the high category. Energy density was the amount of energy contained in each weight of food $(\mathrm{kJ} / \mathrm{g})$ or kilocalories per gram of food weight $(\mathrm{kcal} / \mathrm{g})$ (USDA, 2012). Energy density was positively related to palatability. If the energy density was high, the palatability was also high. Palatability was related to good taste, thereby increasing appetite and increasing food consumption. As a rule, energy-dense foods are palatable but not satiating, whereas foods with low energy density are more satiating but less palatable. Low-energy-density foods are typically those that contain the most water and the least fat (Drewnowski, 1998).

\subsection{Dietary fiber}

There are no special specifications for the dietary fiber content of baby biscuits. The most common form of fiber in insects was chitin. Chitin was a water-insoluble fiber derived from the exoskeleton. Chitin content in insect species ranged from $2.7-49.8 \mathrm{mg} / \mathrm{kg}$ (fresh) and between $11.6-137.2 \mathrm{mg} / \mathrm{kg}$ (dry matter). Chitin is a longchain polymer $\mathrm{N}$-acetyl glucosamine derived from glucose. Some studies suggest that chitin acts as a food fiber, implying that the food fiber content of insects was high, especially in species with hard exoskeletons (Huis et al., 2013). Wood grasshoppers have several body parts with hard exoskeletons such as the head and legs. The head and legs parts of the grasshopper have a higher content of chitin compared to the chest and stomach parts of the wood grasshopper (Huis et al., 2013; Kourimska and Adámková, 2016). Therefore, to make wood grasshopper flour with lower dietary fiber content can be done by removing the head and legs parts during the process of making wood grasshopper flour. Fiber content that is too high in a food product can reduce the quality of protein so that protein digestibility also decreases and can result in a lack of protein storage in the body. If the protein in the body was lacking, it will result in growth disorders in children because the protein was needed for the growth process.

\subsection{Zinc}

The zinc content of wood grasshopper flour was still lower when compared to previous studies conducted in Mexico (Blásquez et al., 2012; Huis et al., 2013). This 
could be due to the grasshopper species used in this study was different from previous studies. The substitution of wood grasshopper flour for baby biscuits has been proven to increase the zinc content of baby biscuits. However, the zinc content in all formulations does not meet the specification requirements where the baby biscuit zinc content should be $2.5-3 \mathrm{mg} / 100 \mathrm{~g}$ (Ministry of Health RI, 2016). In general, mineral salts were not significantly affected by chemical and physical treatment during processing. In the presence of oxygen, some minerals including zinc are likely to be oxidized to higher valves but do not affect their nutritional value. Although some food components are damaged in the process of roasting food, the process does not affect the mineral content in food. Conversely, heat treatment will greatly affect the absorption or use of some minerals, mainly through bond breaking, which makes these minerals less absorbable even if physiologically required (Walingo, 2014; Oghbaei and Prakash, 2016).

\subsection{Iron}

The iron content in all formulations has not been able to meet the specification requirements where the iron content requirement for baby biscuits is $5-6 \mathrm{mg} / 100$ $\mathrm{g}$ (Ministry of Health RI, 2016). Same with zinc, the iron content of wood grasshopper flour was lower compared to previous studies conducted in Mexico (Blásquez et al., 2012; Melo-Ruiz et al., 2015). This could be due to the grasshopper species used in this study was different from previous studies. The low iron content in wood grasshopper flour can also be caused by the process of making wood grasshopper flour itself. Specifically, environmental factors that affect iron damage include heat, air, light, and humidity. Iron stability depends on several factors including the nature of the carrier, particle size and exposure to heat, humidity, and air. Iron can also be damaged or lost by physical separation, for example in the milling process. In the manufacture of wood grasshoppers flour, dried wood grasshoppers undergo a process of milling using a blender to turn down the particles. The shape and texture of the particles and the technical conditions of the grinding, especially the extraction rate, were important in determining the level of mineral loss (Oghbaei and Prakash, 2016).

\subsection{Contribution to nutrition adequacy}

The daily value for the four formulations is represented in Table 6. Percent daily values are based on Recommended Dietary Allowance (RDA) of children aged 12-24 months. Baby biscuits with wood grasshopper flour substitution which most suitable and approach to the specification requirements of Indonesian regulation about complementary food were F1 formulation or baby biscuits with wood grasshopper flour substitution as much as 5\%. The F2 and F3 formulations were also accordance with the specification requirements, but the protein and fat content of F2 and F3 were greater than F1. The organoleptic test results of baby biscuits with wood grasshopper flour substitution which can be accepted by panelists besides the control formulation (F0) is F1 formulation. Therefore, based on the results of nutrient content analysis and organoleptic tests, the formulation was chosen to be the standard or benchmark in determining serving sizes is F1 formulation or baby biscuits with a substitution of wood grasshopper as much as $5 \%$. The serving size of baby biscuits was determined based on $1 / 3$ fulfilment of the adequacy of baby protein in one consumption (Dewey and Brown, 2003). Contribution per serving of baby biscuits was determined based on the results of energy and nutrient content analysis compared to the Recommended Dietary Allowance (RDA) (LIPI, 2004). The serving size of baby biscuits to fulfil $1 / 3$ or $33 \%$ of the adequacy of baby protein based on F1 biscuits with a protein content of $14.28 \%$ is as much as 6 pieces of biscuits $(60 \mathrm{~g})$ per day. The recommended consumption of baby biscuits for children aged 12-24 months is to give biscuits 3 times per day ( 2 pieces for once consumption). Biscuits can be given for morning, afternoon and evening snacks.

\subsection{Sensory characteristics of wood grasshopper biscuits}

The result of the sensory evaluation of the biscuits is as presented in Table 7. The panel scores for taste, color, aroma, and texture acceptability increased with increase in the level of wood grasshopper flour substitution. This implies that the more the wood grasshopper flour, the lesser its acceptability. The color of all biscuits with grasshopper flour substitution was rated liked by the panelists. However, the most preferred biscuit with wood grasshopper flour substitution is F1 biscuits. Analyzing the color of biscuits (Table 7), it was observed that the addition of wood grasshopper flour significantly darkened the surface of biscuits when compared to the control. One of the factors that contribute to the color of biscuits was caused by Maillard reactions between reducing sugar and amino acids. As a result of this nonenzymatic reaction, high-molecular-weight macromolecule materials known as melanoidins were formed during baking (Krystyjan et al., 2015).The darker color of biscuits enriched with wood grasshopper flour was also affected by the wood grasshopper flour itself, which has a much darker color than wheat flour. Biscuits baked with the addition of wood grasshopper flour, were significantly harder than the control sample. One of the factors that contributed to the biscuit's texture was caused by the decrease in flour due to the substitution of 
Table 6. Contribution to nutrition adequacy

\begin{tabular}{|c|c|c|c|c|c|c|c|c|}
\hline \multicolumn{9}{|c|}{ Serving size : 6 pieces $(60 \mathrm{~g})$ per day } \\
\hline$\overline{\text { Sample }}$ & & Energy (kcal) & Protein $(\mathrm{g})$ & Fat (g) & Carbohydrate (g) & Dietary fiber $(\mathrm{g})$ & Zinc (mg) & Iron $(\mathrm{mg})$ \\
\hline \multirow{3}{*}{ F0 } & Product contains & 277 & 6.36 & 11.98 & 36.05 & 3.75 & 0.045 & 0.17 \\
\hline & RDA & 1125 & 26 & 44 & 155 & 16 & 4 & 8 \\
\hline & $\%$ RDA & $25 \%$ & $24 \%$ & $27 \%$ & $23 \%$ & $23 \%$ & $1.12 \%$ & $2.10 \%$ \\
\hline \multirow{3}{*}{$\mathrm{F} 1$} & Product contains & 227 & 8.57 & 11.8 & 34.17 & 6.78 & 0.05 & 0.24 \\
\hline & RDA & 1125 & 26 & 44 & 155 & 16 & 4 & 8 \\
\hline & $\%$ RDA & $25 \%$ & $33 \%$ & $27 \%$ & $22 \%$ & $42 \%$ & $1.21 \%$ & $3 \%$ \\
\hline \multirow{3}{*}{$\mathrm{F} 2$} & Product contains & 287 & 9.22 & 13.18 & 32.83 & 9.77 & 0.05 & 0.22 \\
\hline & RDA & 1125 & 26 & 44 & 155 & 16 & 4 & 8 \\
\hline & $\%$ RDA & $26 \%$ & $35 \%$ & $30 \%$ & $21 \%$ & $61 \%$ & $1.26 \%$ & $2.70 \%$ \\
\hline \multirow{3}{*}{ F3 } & Product contains & 284 & 9.87 & 13.35 & 31.27 & 11.85 & 0.06 & 0.24 \\
\hline & $\mathrm{RDA}$ & 1125 & 26 & 44 & 155 & 16 & 4 & 8 \\
\hline & $\%$ RDA & $25 \%$ & $38 \%$ & $30 \%$ & $20 \%$ & $74 \%$ & $1.63 \%$ & $3 \%$ \\
\hline
\end{tabular}

Table 7. Sensory characteristic of wood grasshopper biscuits

\begin{tabular}{ccccc}
\hline Sample & $\begin{array}{c}\text { Taste } \\
\text { Mean } \pm \text { SD }\end{array}$ & $\begin{array}{c}\text { Colour } \\
\text { Mean } \pm \text { SD }\end{array}$ & $\begin{array}{c}\text { Aroma } \\
\text { Mean } \pm \text { SD }\end{array}$ & $\begin{array}{c}\text { Texture } \\
\text { Mean } \pm \text { SD }\end{array}$ \\
\hline F0 & $1.36 \pm 0.64^{\mathrm{a}}$ & $1.40 \pm 0.58^{\mathrm{a}}$ & $1.48 \pm 0.65^{\mathrm{a}}$ & $1.60 \pm 0.76^{\mathrm{a}}$ \\
F1 & $2.12 \pm 0.53^{\mathrm{b}}$ & $2.24 \pm 0.60^{\mathrm{b}}$ & $2.48 \pm 0.59^{\mathrm{b}}$ & $2.08 \pm 0.57^{\mathrm{b}}$ \\
F2 & $2.44 \pm 0.71^{\mathrm{bc}}$ & $2.04 \pm 0.61^{\mathrm{bc}}$ & $2.68 \pm 0.48^{\mathrm{bc}}$ & $2.40 \pm 0.76^{\mathrm{bc}}$ \\
F3 & $3.08 \pm 0.76^{\mathrm{cd}}$ & $2.48 \pm 0.92^{\mathrm{bcd}}$ & $2.76 \pm 0.72^{\mathrm{bcd}}$ & $2.40 \pm 0.70^{\mathrm{bcd}}$ \\
\hline
\end{tabular}

*Values with different superscripts among the same column were significantly different $(\mathrm{p}<0.05)$

wood grasshoppers flour. Wheat flour was played a role in providing elastic properties because it contains gluten which is wheat protein that is insoluble in water. Gluten and gliadin are two main fractions of gluten. Whereas, glutenin is necessary to make an elastic and consistent structure in dough. Gliadin is responsible for viscosity and extensibility of a dough system (Meybodi et al., 2015). The taste of F1 biscuits with grasshopper flour substitution was judged liked by the panelists. The most preferred is F1 biscuits. The addition of wood grasshopper flour is very influential on the taste of biscuits produced. Wood grasshopper flour has a bitter taste. The aroma of all biscuits with grasshopper flour substitution was judged liked by the panelists. However, the most preferred is F1 biscuits. Analyzing the aroma of biscuits (Table 7), it was observed that the addition of wood grasshopper flour significantly fishy smelled of biscuits when compared to the control.

\section{Conclusion}

The serving size of baby biscuits with the substitution of wood grasshopper flour are 6 pieces $(60$ g). Consumption of one serving size of baby biscuits with the substitution of wood grasshopper flour can meet $24-38 \%$ of the RDA of children's protein aged 12-24 months in all formulations. However, zinc and iron content in all formulations has not been able to meet the specification requirements of Indonesian regulation about complementary food.

\section{Acknowledgments}

We extend our thanks to the Center of Nutritional Laboratory, Diponegoro University Semarang for providing our research tools and sites.

\section{References}

Agency of Health Research and Development. (2013). Indonesia Basic Health Research 2013. Indonesia: Agency of Health Research and Development.

Ahmed, M.A.R.H., Mustafa, A.I., Hussan, H.A.R. and Elfaki, A.E. (2016). Proximate Composition, Protein Digestibility, Starch Digestibility, Physical Properties and Sensory Evaluation of Decorticated Sorghum and Maize Biscuits Supplemented with Chickpea Flour. International Journal of Current Research and Academic Review, 4(5), 1-11. https:// doi.org/10.20546/ijcrar.2016.405.001

Alves, J.F.R., Britto, R.P.A., Ferreira, H.S., Sawaya, A.L. and Florêncio, T.M.M.T. (2014). Evolution of the biochemical profile of children treated or undergoing treatment for moderate or severe stunting : consequences of metabolic programming?. Jornal de Pediatria, 90(4), 356-362. https:// doi.org/10.1016/j.jped.2013.12.007

AOAC. (1995). Official Methods of Analysis of The Association of Analytical Chemists. Wasington D.C., USA: AOAC. 
Blásquez, J.R.-E., Moreno, J.M.P. and Camacho, V.H.M. (2012). Could grasshoppers be a nutritive meal? Food Nutrition Science, 3(2), 164-175. https:// doi.org/10.4236/fns.2012.32025

BSN. (2005). Complementary Food - Part 2: Biscuits. Jakarta:National Standardization Agency.

Das, M. and Mandal, S.K. (2013). Assessment of nutritional quality and anti-nutrient composition of two edible grasshoppers (Orthoptera: Acrididae) - a search for new food alternative. International Journal of Medicine and Pharmaceutical Sciences, 3 (5), 31-48.

Demands, T. (2916). The Pediatric Methionine Requirement Should Incorporate Remethylation Potential. Advance Nutrition, 7(3), 523-534. https:// doi.org/10.3945/an.115.010843

Dewey, K. and Brown, K. (2003). Update on technical issues concerning complementary feeding of young children in developing countries and implications for intervention programs. Food Nutrition Bulletin, 24
(1), 5-28.
https://

doi.org/10.1177/156482650302400102

Drewnowski, A. (1998). Energy Density, Palatability, and Satiety: Implication for Weight Control. Nutrition Review, 56(12), 347-353. https:// doi.org/10.1111/j.1753-4887.1998.tb01677.x

Ghosh, S., Smriga, M., Vuvor, F., Suri, D., Mohammed, H., Armah, S.M. and Scrimshaw, N.S. (2010). Effect of Lysine Supplementation on Health and Morbidity in Subjects Belonging to Poor Peri-urban Households in Accra, Ghana. American Journal of Clinical Nutrition, 92(4), 928-939. https:// doi.org/10.3945/ajen.2009.28834

Huis, A.V., Itterbeeck, J.V., Klunder, H., Mertens, E., Halloran, A., Muir, G. and Vantomme, P. (2013). Edible insect: future prospect for food and feed security. Rome: FAO.

Jiang, M.-Y. and Cai, D.-P. (2011). Oral Arginine Improves Linear Growth of Long Bones and The Neuroendocrine Mechanism. Neuroscience Bulletin, 27(3), 156-62. https://doi.org/10.1007/s12264-0111051-3

Kourimska, L. and Adámková, A. (2016). Nutritional and sensory quality of edible insects. NFS Journal, 4, 22-26. https://doi.org/10.1016/j.nfs.2016.07.001

Krystyjan, M., Gumul, D., Ziobro, R., Korus, A. (2015). The fortification of biscuits with bee pollen and its effect on physicochemical and antioxidant properties in biscuits. LWT - Food Science and Technology, 63 (1), 640-646. https://doi.org/10.1016/ j.lwt.2015.03.075

LIPI. (2004). Recommended Dietary Allowances (RDA).
Jakarta: Widyakarya National Food.

Marono, S., Piccolo, G., Laponte, R., Meo, C., Attia, Y., Nizza, A. and Bovera, F. (2015). In vitro crude protein digestibility of Tenebrio molitar and Hermetia illucens insect meals and its correlation with chemical composition traits. Italian Journal of Animal Science, 14, 338-343. https:// doi.org/10.4081/ijas.2015.3889

Melo-Ruiz, V., Sandoval-Trujillo, H., Quirino-Barreda, T., Sánchez-Herrera, K., Díaz-García, R. and CalvoCarrillo, C. (2015). Chemical composition and amino acids content of five species of edible Grasshoppers from Mexico. Emirates Journal of Food and Agriculture, 27(8), 654-658. https:// doi.org/10.9755/ejfa.2015.04.093

Meybodi, N., Mohammadifar, M. and Feizollahi, E. (2015). Gluten-free bread quality: a review of the improving factors. Journal of Food Quality and Hazard Control, 2, 81-85.

Ministry of Health RI (2018). Main Results of Riskesdas 2018. Indonesia: Indonesian Health Research and Development Agency.

Ministry of Health RI. (2016). Regulation of Health's Minister of the Republic of Indonesia Number 51 of 2016 about Standard for Nutrition Complementary Products, p. 9-18. Jakarta. Indonesian Health Research and Development Agency.

Mohamed, G., Sulieman, A., Soliman, N. and Bassiuny, S. (2014). Fortifications of biscuits with fish proteinconcentrate. World Journal of Dairy Food Science, 9(2), 242-9.

Oghbaei, M. and Prakash, J. (2016). Effect of primary processing of cereals and legumes on its nutritional quality: A comprehensive review. Cogent Food and Agriculture, 36(1), 1-14. https:// doi.org/10.1080/23311932.2015.1136015

Paul, A., Frederich, M., Uyttenbroeck, R., Hatt, S., Malik, P., Lebecque, S. and Malik, H., Miazek, K., Goffin, D., Willems, L., Deleu, M., Fauconnier, M.L., Richel, A., De Pauw, E., Blecker, C., Monty, A., Francis, F., Haubruge, E. and Danthine, S.M. (2016). Grasshoppers as a food source? A review. Biotechnology, Agronomy and Society and Environment, 20(S1), 337-352.

Public Health Office. (2017). Provincial Health Profile in Yogyakarta. Yogyakarta: DIY Health Office.

Semba, R.D., Shardell, M., Sakr, F.A., Moaddel, R., Trehan, I., Maleta, K.M., Ordiz, M.I., Kraemer, K., Khadeer, M.A.,Ferrucci, L. and Manary, M.J. (2016). Child stunting is associated with low circulating essential amino acids. EBioMedicine, 6, 246-252. https://doi.org/10.1016/ 
j.ebiom.2016.02.030

Shewry, P. and Hey, S. (2015). The contribution of wheat to human diet and health. Food Energy Security, 4(3), 178-202. https://doi.org/10.1002/ fes3.64

Teodorowicz, M., Neerven, V.J. and Savelkoul, H. (2017). Food processing: the influence of the Maillard reaction on immunogenicity and allergenicity of food proteins. Nutrients, 9(8), 835. https://doi.org/10.3390/nu9080835

UNICEF. (2019). Malnutrition rates remain alarming: stunting is declining too slowly while wasting still impacts the lives of far too many young children. Retrieved from UNICEF website: https:// data.unicef.org/topic/nutrition/malnutrition/

USDA. (2012). NP and P of Dietary Energy Density and Body Weight: A Review of the Evidence. Virginia, USA: CNPP-USDA.

Walingo, M.K. (2009). Indigenous food processing methods that improve zinc absorption and bioavailability of plant diets consumed by the Kenyan population. African Journal of Food, Agroculture, Nutrition and Development, 9(1), 524535. https://doi.org/10.4314/ajfand.v9i1.19210

WHO. (2002). Protein and amino acids requirement in human nutrition, p. 171-181. Geneva, Switzerland: World Health Organization.

Youssef, H.M.K.E. (2015). Assessment of Gross Chemical Composition, Mineral Composition, Vitamin Composition and Amino Acids Composition of Wheat Biscuits and Wheat Germ Fortified Biscuits. Food Nutrition Science, 6, 845853. https://doi.org/10.4236/fns.2015.610088

Zambrano, V.M., Dutta, B., Mercer, D.G., Maclean, H.L. and Touchie, M.F. (2019). Assessment of moisture content measurement methods of dried food products in small-scale operations in developing countries : A review. Trends in Food Science and Technology, 88, 484-496. https://doi.org/10.1016/j.tifs.2019.04.006 